findings could be integrated into Great Britain's overall economic programme. Mr. Morrison believes that the first problem of economic recovery is one of increased productivity, and the key to this is to be found in more knowledge--knowledge both of technical processes and also of human relationships. The Government is fully aware of the importance of the issue and is prepared to support State and private research with every financial help; thus the trend of increase in cost- $£ 470,000$ in $1938, £ 2$ millions last year and an estimated $£ 2 \frac{1}{2}$ millions next year-is not a matter for concern but a sign of the ever-growing importance of research and a pointer to bigger things to come. Recent material results have convinced Mr. Morrison that the money is well spent, and he referred, for example, to the technical advances made in pottery firing operations, infra-red drying of paints, fitting of shoes, adjusting of peak electrical loads, production of linen, improvement of iron foundries and development of 'nodular cast-iron', design of more efficient domestic grates, scientific research into better houses, and the improvement of road surfaces. It is important that manufacturers should bear in mind the improvement of quality and lowering of costs in addition to increased productivity. All these problems can be solved by more scientific investigation, and Mr. Morrison considers that research is the spearhead of the advance of industry by which we will determine whether we are going to hold our place in competitive world industry or degenerate into a third-rate Power. Not only must the value of research be recognized, but also the conditions of scientific workers must be improved and their status acknowledged. Responsible people do realize these points, but are they fully understood by the general public? The research associations must publicize their activities and see that the world knows of the excellent results being obtained by British research effort.

\section{Operational Research Club}

Aвоur a year ago, a number of men of science interested in operational research began meeting together in the rooms of the Royal Society to discuss the development of methods and the application of this field of science. Papers were read and discussed in connexion with road traffic, productivity in the cotton industry, use of fertilizers by farmers, the organisation of inspection in the steel industry, etc. An "Operational Research Club" has now grown out of these meetings, and a healthy programme of papers for this session has been planned. In order to main. tain the informal nature of the meetings, it has been necessary to limit the membership; but it is intended to include representatives from most of the oper. ational research teams working in industrial and other civil fields, together with some from the defence services. The honorary secretary of the Club is Mr. D. Neville-Jones, 24 Rutland Gate, London, S.W.7.

\section{Motor Industry in Britain}

A Clear picture of the British motor industry is presented in a broadsheet prepared by Political and Economic Planning (No. 284). The broadsheet traces first the development of the industry before the War, examining factors such as taxation which influenced demand in the United Kingdom and the growth of the Nuffield Organisation, the Ford Motor Co., the Austin Motor Co., Vauxhall Motors, the Rootes Group, and the Standard Motor Co. The effect of conversion to war demands and subsequent reconversion is then described, and, after a review of the post-war structure and home demand, the labour force of the industry is analysed, and its trade organisations and export markets are considered. The broadsheet makes no recommendations as to future policy, but indicates that if the shortage of foreign exchange could be left out of account, there is sufficient shortage of vehicles in the world to give both Britain and the United States ample scope for some time to come. Such comparison with pre-war figures as is practicable suggests that the industry's labour force is about 25 per cent greater than before the War.

\section{The Original Wright Aeroplane}

THE original Wright aeroplane of 1903-the first power-driven man-carrying aeroplane to make a free, controlled and sustained flight-was lent by $\mathrm{Mr}$. Orville Wright in 1928 for exhibition in the Science Museum, London, for an initial period of five years. On October 18 it was taken down for packing in crates in readiness for its return to the United States. This machine was designed and built by the brothers Wilbur and Orville Wright at Dayton, Ohio, in 1903, and was flown at Kitty Hawk, North Carolina, on December 17. The first flight lasted 12 sec. and was made in a wind of about twenty miles per hour, the machine being piloted by Mr. Orville Wright; altogether four flights were made on the morning of that day. The last flight was one of $59 \mathrm{sec}$., when the distance covered was $852 \mathrm{ft}$.; the machine was then overturned by a gust of wind while left unattended, and the damage caused prevented further experiments at that time. After these first flights, the aeroplane was preserved in the Wright Laboratory at Dayton. Certain parts which were damaged were replaced by Mr. Orville Wright himself, and the machine was restored to its original condition. An exact replica of the aeroplane has now been made and will be exhibited in its place at the Science Museum. Dr. H. Shaw, director of the Museum, is to accompany the machine to the United States, where it will be preserved in the National Air Museum, Smithsonian Institution, Washington, D.C. It should arrive there in good time for the forty-fifth anniversary of its first flight on December 17, 1903.

\section{Economics and State Control}

Prow. G. C. Aluzn's inaugural lecture at University College, London, on March 4, 1948, which has now been published (London: H. K. Lewis and Co., Ltd. Pp. iit 18. 2s. 6d. net), emphasizes that while the trend of economic opinion in pre-war days was in favour of a more active intervention by the State in economic affairs, such intervention was not inconsistent with the preservation of the system of private enterprise ; it was deemed necessary for improving the operation of the system. Present policy, however, of State intervention goes much further than the achievement of 'full employment', an acceptable distribution of the national income, and the promotion of structural adjustments in industry by fiscal or financial measures. Prof. Allen devotes most of his lecture to an examination of the economic implications of the policy at present being pursued both in the nationalization of industry and in the guidance of private industry by substitutes for the compulsion of the market. He points out the im. portance in industries that depend to any extent upon innovation of being able to attract the outstanding personalities with initiative and organising capacity ; the administration and efficiency of such industries 